\title{
STUDI EKSPLORASI MOTOR BAKAR BERBAHAN BAKAR GANDA DALAM UPAYA MENDUKUNG PENGEMBANGAN MOTOR BAKAR BERBAHAN BAKAR GAS ALAM
}

\author{
Sony Harbintoro, Pujiyanto \\ Balai Besar Logam dan Mesin, Kementerian Perindustrian \\ Jl. Sangkuriang 12 Bandung - Jawa Barat \\ Email: sonystrada@yahoo.com
}

\begin{abstract}
ABSTRAK
Penelitian mengenai eksplorasi motor bakar berbahan bakar ganda dalam upaya mendukung pengembangan motor bakar berbahan bakar gas alam telah dilaksanakan di MIDC Bandung. Pada motor bakar pembakaran dalam, berbahan bakar bensin dan berbahan bakar gas terdapat beberapa perbedaan, studi ini menganalisis dampak dari penggunaan bahan bakar gas terhadap komponenkomponen motor bakar berbahan bakar bensin. Penelitian dilakukan dengan melakukan studi pustaka, pencarian formula perhitungan bahan bakar gas, melakukan identifikasi desain konseptual terhadap motor bakar yang digunakan sebagai objek penelitian, melakukan pengujian performa motor bakar, dan melakukan analisa data. Dari hasil pengujian terhadap motor bakar yang sama dengan menggunakan bahan bakar bensin dan gas LPG didapat data temperatur pada beberapa komponen motor bakar yang berhubungan dengan proses pembakaran. Dari hasil studi didapat bahwa tidak ada perbedaan temperatur yang signifikan pada beberapa komponen motor bakar yang menggunakan bahan bakar bensin dan bahan bakar gas LPG.
\end{abstract}

Kata kunci: eksperimental, motor bakar, berbahan bakar ganda, gas alam

\begin{abstract}
Research on the exploration of dual-fueled internal combustion engine in order to support the development of internal combustion engine powered by natural gas has been carried out in the Design Engineering Section and Testing is done in MIDC Bandung. On internal combustion engine, gasolinefueled and gas-fueled have some differences, this study analyzed the impact of the use of gas as the fuel of gasoline engine. The research was conducted by studying the literature, the search calculation formula of fuel gas, identification the conceptual design of the engine which is used as the object of study, test the performance of the engine, and perform data analysis. From the results of tests on the same internal combustion engine using gasoline and LPG, the temperature data obtained on several components related to engine combustion process. From the results of this study its found that there was no significant difference in the temperature of engine components that use gasoline or LPG fuel.
\end{abstract}

Keywords: experimental, engine, dual fuel, natural gas

\section{PENDAHULUAN}

Dalam rangka mendukung kebijakan pemerintah melalui Peraturan Presiden No. 15 Tahun 2012 tentang perubahan konsumen pengguna BBM bersubsidi, pembatasan penggunaan jenis BBM tertentu oleh pengguna secara bertahap, dan badan pengatur melakukan pengaturan, pengawasan dan verifikasi terhadap kelancaran dan ketepatan pelaksanaan pendistribusian jenis BBM tertentu bagi konsumen pengguna, maka bidang penelitian dan pengembangan Balai
Besar logam dan Mesin (BBLM) telah melakukan penelitian terhadap sistem motor bakar berbahan bakar minyak (BBM) menjadi bahan bakar gas (BBG). Untuk mengubah pengunaan bahan bakar gas pada mesin yang awalnya didesain untuk bahan bakar minyak tidaklah mudah dalam aspek mempertahankan fungsi dari setiap komponen motor bakar supaya tetap seperti yang dirancang. 
Ada beberapa hal yang perlu diperhitungkan untuk melakukan hal tersebut, seperti daerah jangkauan kompresi, sistem pendinginan, sistem pelumasan, perubahan / modifikasi yang diperlukan pada komponenkomponen tertentu, dan sebagainya.

Untuk menelaah hal tersebut, strategi yang digunakan adalah dengan metode reverse engineering. Reverse engineering (rekayasa balik) adalah pengembangan data teknik yang diperlukan untuk menunjang item komponen produksi yang telah dikembangkan pada masa lalu untuk digunakan dalam membangun sistem yang baru. Dalam hal ini, mungkin saja data teknik yang kita butuhkan tidak akan lengkap, data ukur yang kita lakukan terdapat "kesalahan", dll. Tujuan dari rekayasa balik ini adalah untuk identifikasi persyaratan fungsi dari suatu mekanisme keteknikan, melalui eksplorasi pada sistem yang ada pada motor bakar yang dijadikan referensi objek penelitian.

Keuntungan rekayasa balik pada penelitian ini adalah untuk menjaga atau memperbaiki persyaratan fungsi dari mekanisme keteknikan pada kondisi performa puncak dengan perbaikan yang terdokumentasi. Dengan memberikan nilai tambah pada sistem/komponen yang mengalami rekayasa balik memungkinkan peningkatan/perbaikan kualitas produk dan mengurangi ongkos produksi serta harga produk yang lebih murah; menambah efisiensi \& produktivitas pada sistem produksi, biaya lebih murah dalam waktu yang lebih cepat.

Sasaran yang ingin dicapai dari penelitian ini adalah didapatkan data hasil rekayasa balik untuk pengembangan motor bakar berbahan bakar gas alam.

\section{TINJAUAN PUSTAKA}

Motor bakar berbahan bakar gas, secara prinsip kerja sebenarnya mirip dengan yang terjadi pada motor bakar bensin (menggunakan karburator/pompa injeksi) dan motor bakar diesel, baik yang 4 langkah maupun 2 langkah ${ }^{(1)}$. Konstruksi dasar motor bakar secara umum adalah sama, yang membedakannya adalah komponen bahan bakar dan jaringannya. Hal yang paling mendasar pada semua motor bakar adalah bahwa perubahan bahan bakar tidak mengubah langkah kerja dari motor bakar itu sendiri. Misalnya motor bakar yang asalnya berprinsip 4 langkah dengan diganti bahan bakar gas, maka motor bakar itu akan tetap menggunakan prinsip 4 langkah.

Perubahan bahan bakar dari bahan bakar minyak ke bahan bakar gas, dapat dimungkinkan dengan melakukan perubahan / modifikasi pada sistem bahan bakar dan sistem pengapian. Namun demikian hal ini tidak sesederhana yang dibayangkan, karena modifikasi dan penggantian itu berpengaruh pada sistem yang lain pada motor bakar, misalnya sistem pengolian dan sistem pendinginan.

Motor bakar adalah mesin yang menggunakan energi termal untuk melakukan kerja mekanik, yaitu dengan cara mengubah energi kimia dari bahan bakar menjadi energi panas, dan menggunakan energi tersebut untuk melakukan kerja mekanik. Energi termal diperoleh dari pembakaran bahan bakar pada masin itu sendiri. Jika ditinjau dari cara memperoleh energi termal ini (proses pembakaran bahan bakar), maka motor bakar dapat dibagi menjadi 2 golongan yaitu: motor pembakaran luar dan motor pembakaran dalam. Pada motor pembakaran luar, proses pembakaran bahan bakar terjadi di luar mesin itu, sehingga untuk melaksanakan pembakaran digunakan mesin tersendiri. Panas dari hasil pembakaran bahan bakar tidak langsung diubah menjadi tenaga gerak, tetapi terlebih dulu melalui media penghantar, baru kemudian diubah menjadi tenaga mekanik. Misalnya pada ketel uap (boiler) dan turbin uap. Pada motor pembakaran dalam, proses pembakaran bahan bakar terjadi di dalam mesin itu sendiri, sehingga panas dari hasil pembakaran langsung bisa diubah menjadi tenaga mekanik. Misalnya : pada turbin gas, motor bakar torak dan mesin propulsi pancar gas.

Proses pembakaran pada motor bakar terjadi akibat dari bahan bakar yang masuk ke dalam ruang bakar terbakar dengan penyalaan busi atau dengan sendirinya akibat dari tingginya suhu udara kompresi dalam ruang bakar $^{(1)}$. 
Secara prinsip motor bakar torak, terdapat dua kelompok yang dikenal dalam motor bakar yaitu motor bakar bensin (otto) dan motor bakar diesel. Perbedaan mendasar pada dua kelompok ini antara lain bahan bakar yang digunakan dan sistem penyalaan bahan bakar yang digunakan. Untuk motor bakar bensin menggunakan bensin sebagai bahan bakar dan busi sebagai alat penyalaan pembakaran. Sedangkan motor bakar diesel menggunakan minyak diesel (solar/bio diesel) sebagai bahan bakar dan kompresi tinggi sebagai alat penyalaan pembakaran ${ }^{(7)}$.

Motor bakar berbahan bakar gas alam adalah motor bakar dengan sistem pembakaran dalam yang dioperasikan menggunakan gas alam sebagai bahan bakar, seperti LPG, CNG, batu bara gas, biogas dan lain-lain. Motor bakar gas alam banyak diaplikasikan pada motor bakar stasioner, namun sekarang sudah banyak dikembangkan untuk penggerak kendaraan pribadi maupun angkutan massal. Penggunaan gas alam sebagai bahan bakar bisa diaplikasikan secara bersama (bahan bakar minyak dicampur dengan bahan bakar gas pada ruang bakar melalui mekanisme tertentu), tetapi ada juga yang diaplikasikan secara khusus (dedicated). Penggunaan bahan bakar campuran bahan bakar gas alam dengan bahan bakar minyak biasa dikenal sebagai dual fuel engine, sedangkan yang murni menggunakan gas alam dikenal sebagai dedicated natural gas engine.

Pengklasifikasian motor bakar gas alam sama dengan motor bakar minyak, yaitu 2 langkah dan 4 langkah. Begitu juga dengan siklusnya, untuk siklus 2 langkah dan 4 langkah sama dengan siklus motor bakar yang menggunakan bahan bakar minyak. Yang membedakan dari sistem motor bakar gas alam dengan motor bakar minyak adalah sistem bahan bakarnya sendiri. Dengan sistem bahan bakar yang berubah akan berpengaruh pada sistem yang lain, yaitu konstruksi, sistem pendinginan, sistem pelumasan, sistem kelistrikan dsb.

Motor bakar gas alam dilengkapi dengan sistem bahan bakar yang berupa konverter kit, tabung gas, dan pengatur pengumpan bahan bakar. Secara konstruksi, ada perbedaan daerah operasi di kisaran antara daerah kompresi motor bakar bensin dan motor bakar diesel. Hal ini akan menyebabkan perlunya modifikasi ruang bakar, dan sistem pengaturan katup. Komposisi bahan bakar gas alam menyebabkan temperatur pembakaran di ruang bakar lebih tinggi daripada bahan bakar bensin ataupun solar. Hal ini menyebabkan diperlukannya sistem pendinginan yang sesuai agar motor bakar tidak mengalami panas berlebihan (over heat). Begitu juga dengan pengolian, dengan temperatur yang lebih tinggi ini diperlukan sirkulasi pengolian yang lebih tinggi dan juga perlu karakteristik oli yang berbeda dengan motor bakar bensin atau diesel.

Titik bakar bahan bakar gas alam berbeda dengan bahan bakar bensin ataupun diesel $^{(2)}$. Hal ini menyebabkan sistem pengaturan pemasukan bahan bakar dan udara perlu dimodifikasi hingga diperoleh efisiensi pembakaran yang ideal. Gambar berikut ini adalah ilustrasi sistem motor bakar gas alam.

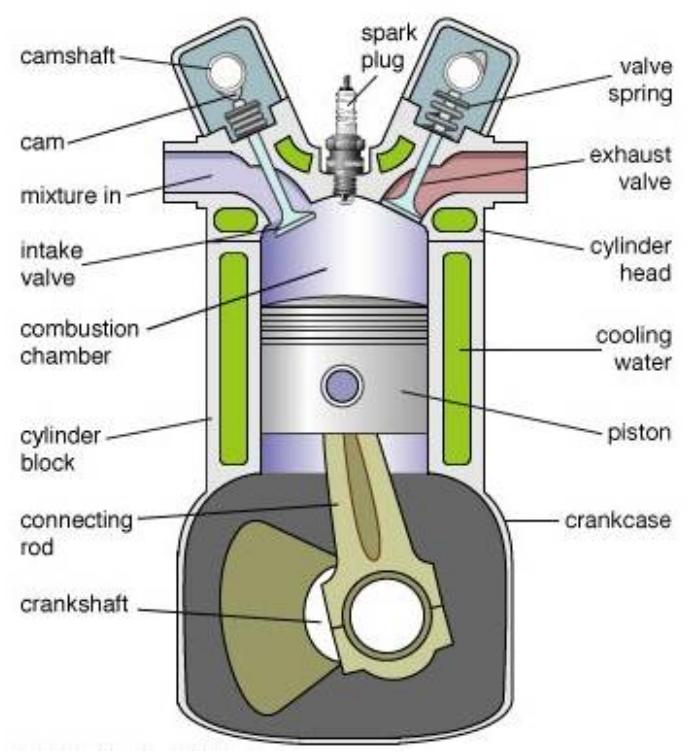

Gambar 1. Bagian-bagian motor bakar gas alam

Secara konstruksi bagian-bagian motor bakar gas alam seperti terlihat pada gambar di atas, bahwa tidak terlihat perbedaan mencolok antara motor bakar gas alam dengan motor bakar bensin. Namun, perlu diamati lebih spesifik karena bahan bakar yang digunakan berbeda, sehingga diperlukan perhitungan ulang menyangkut hal-hal yang terpengaruh oleh adanya perubahan jenis bahan bakar. 
Kandungan dari gas alam terdiri atas metana dan mencakup sejumlah konstituen/unsur yang lain. Komposisi bahan bakar gas lainnya umumnya lebih kompleks, tetapi setidaknya mudah diperoleh. Tabel 1 dibawah ini menggambarkan berbagai komposisi didalam bahan bakar gas, baik alam dan sintetis.

Informasi mengenai komposisi bahan bakar cair atau padat pada umumnya jauh lebih terbatas daripada untuk bahan bakar gas. Komposisi molekul pada bahan bakar cair biasanya menjadi campuran kompleks dari sejumlah besar spesies hidrokarbon sangat jarang ditemukan. Data komposisi yang paling sering dilaporkan berasal dari analisis akhir, yang terdiri atas pengukuran komposisi unsur bahan bakar, umumnya disajikan sebagai fraksi massa karbon, hidrogen, sulfur, oksigen, nitrogen, dan abu, yang sesuai. Nilai kalor, ukuran pelepasan panas selama pembakaran sempurna, juga dilaporkan dengan analisis akhir. Karakteristik dari sejumlah bahan bakar cair disajikan pada Tabel 2.

Tabel 1. Properti dari bahan bakar gas alam (diambil dari energy efficiency asia org.)

\begin{tabular}{|c|c|c|c|c|c|c|c|c|c|c|}
\hline & $\mathrm{CH}_{4}$ & $\mathrm{C}_{2} \mathrm{H}_{6}$ & $\mathrm{C}_{3} \mathrm{H}_{8}$ & $\begin{array}{c}\text { Other } \\
\text { hydrocarbons }\end{array}$ & $\mathrm{CO}$ & $\mathrm{H}_{2}$ & $\mathrm{H}_{2} \mathrm{~S}$ & $\mathrm{~N}_{2}$ & $\mathrm{CO}_{2}$ & $\begin{array}{c}\text { Heating } \\
\text { value }^{\mathrm{a}} \\
\left(10^{6} \mathrm{~J} \mathrm{~m}^{-3}\right)\end{array}$ \\
\hline \multicolumn{11}{|l|}{ Natural gas } \\
\hline No. 1 & 77.7 & 5.6 & 2.4 & 1.8 & - & - & 7.0 & - & - & - \\
\hline No. $2^{\mathrm{b}}$ & 88.8 & 6.4 & 2.7 & 2.0 & - & - & 0.0004 & - & 0 & 41.9 \\
\hline No. 3 & 59.2 & 12.9 & - & - & - & - & - & 0.7 & 26.2 & 30.7 \\
\hline No. 4 & 99.2 & - & - & - & - & - & - & 0.6 & 0.2 & 36.3 \\
\hline \multicolumn{11}{|l|}{ Refinery gas } \\
\hline No. 1 & 41.6 & 20.9 & 19.7 & 15.6 & - & - & 2.2 & - & - & 68.6 \\
\hline No. 2 & 4.3 & 82.7 & 13.0 & - & - & - & - & - & - & 67.1 \\
\hline No. 3 & 15.9 & 5.0 & - & 2.4 & 14.3 & 50.9 & - & 8.4 & 2.2 & 18.7 \\
\hline Coke oven gas & - & - & - & 35.3 & 6.3 & 53.0 & - & 3.4 & 1.8 & 21.5 \\
\hline Blast furnace gas & - & - & - & - & 26.2 & 3.2 & - & 57.6 & 13 & 3.4 \\
\hline
\end{tabular}

Tabel 2. Properti dari tipe-tipe bahan bakar cair

\begin{tabular}{|c|c|c|c|c|c|c|c|c|}
\hline \multirow[b]{2}{*}{ Gasoline } & \multicolumn{5}{|c|}{ Percent by weight } & \multirow[b]{2}{*}{ Ash } & \multirow{2}{*}{$\begin{array}{l}\text { Specific } \\
\text { gravity }\end{array}$} & \multirow{2}{*}{$\begin{array}{c}\text { Heating } \\
\text { value } \\
\left(10^{6} \mathrm{~J} \mathrm{~kg}^{-1}\right)\end{array}$} \\
\hline & $\mathrm{C}$ & $\mathrm{H}$ & $\mathrm{N}$ & $\mathrm{O}$ & S & & & \\
\hline Kerosene (No. 1) & 86.5 & 13.2 & 0.1 & 0.1 & 0.1 & Trace & 0.825 & 46.4 \\
\hline \multicolumn{9}{|l|}{ Fuel oil } \\
\hline No. 2 & 86.4 & 12.7 & 0.1 & 0.1 & $0.4-0.7$ & Trace & 0.865 & 45.5 \\
\hline No. 4 & 85.6 & 11.7 & 0.3 & 0.4 & $<2$ & 0.05 & 0.953 & 43.4 \\
\hline No. 6 & 85.7 & 10.5 & 0.5 & 0.4 & $<2.8$ & 0.08 & 0.986 & 42.5 \\
\hline
\end{tabular}




\section{METODOLOGI}

\section{Benda kerja dan alat yang digunakan}

Benda kerja/objek yang digunakan pada penelitian ini adalah motor bakar dengan spesifikasi yang ditampilkan pada Tabel 3 sebagai berikut:

Tabel 3. Karakteristik motor bakar objek penelitian (diambil dari Henley Ltd.)

\begin{tabular}{|c|c|c|}
\hline Model & - & 465 \\
\hline Ignition & - & TCI \\
\hline Cooling System & - & Water-cooling \\
\hline In-take Fuel System & - & In-take in Mix \\
\hline Number of Cylinder & - & Four \\
\hline Bore x Stroke & $\left(\mathrm{mm}^{*} \mathrm{~mm}\right)$ & $65 \times 72$ \\
\hline Displacement & (L) & 1.0 \\
\hline RPM & $(\mathrm{r} / \mathrm{min})$ & 1500 \\
\hline RPM in lag (r/min) & $(\mathrm{r} / \mathrm{min})$ & 1000 \\
\hline Gas Pressure & $(\mathrm{kPa})$ & $3-6 \mathrm{kPa}$ \\
\hline Pressure Flutuation & $(\mathrm{kPa})$ & $\leq 0.2 \mathrm{kPa}$ \\
\hline Heat Consumption & $(\mathrm{kJ} / \mathrm{kW} \cdot \mathrm{h})$ & $\leq 11000$ \\
\hline Oil Consumption & $(\mathrm{g} / \mathrm{kW} \cdot \mathrm{h})$ & $\leq 1.5$ \\
\hline Water Temperature & $\left({ }^{\circ} \mathrm{C}\right)$ & $\leq 80$ \\
\hline Oil temperature & $\left({ }^{\circ} \mathrm{C}\right)$ & $\leq 121$ \\
\hline oil pressure & $(\mathrm{kPa})$ & $207-345$ \\
\hline $\begin{array}{l}\text { Fluctuation in } \\
\text { Stability }\end{array}$ & $\%$ & $\leq 0.5 \%$ \\
\hline Starting Power & - & $\mathrm{DC}, 12 \mathrm{~V}$ \\
\hline Cooling System & - & $\begin{array}{l}\text { Cooling } \\
\text { system }\end{array}$ \\
\hline Lubrication & $\mathrm{L}$ & $\begin{array}{c}\text { Pressure } \\
\text { lubrication } \\
\text { and Splash } \\
\text { Fluctuation }\end{array}$ \\
\hline Oil Model & - & $\begin{array}{l}\text { ST/CF4 UP } \\
\text { SG15W-40 }\end{array}$ \\
\hline
\end{tabular}

Motor bakar sebagai objek penelitian dihubungkan dengan generator set dan peralatan tambahan yang ditampilkan pada Tabel 4 berikut ini.
Tabel 4. Alat yang digunakan

\begin{tabular}{|l|c|c|}
\hline Model & - & HL $15 \mathrm{~K}$ \\
\hline Rated Ouput & $\mathrm{KW}$ & 15 \\
\hline Frequency & $\mathrm{Hz}$ & 50 \\
\hline Output Voltage & Volt & $220 / 380$ \\
\hline Current & $\mathrm{A}$ & $72 / 37$ \\
\hline Power Factor & Cos Ø & $1,0 / 0,8$ \\
\hline Displacement & $(\mathrm{L})$ & 1.0 \\
\hline RPM & (r/min) & 1500 \\
\hline Sensor & $\begin{array}{c}\text { pengukur } \\
\text { kecepatan }\end{array}$ & Tachometer \\
\hline Sensor & $\begin{array}{c}\text { pengukur } \\
\text { temperatur }\end{array}$ & Tipe K \\
\hline Water Heater & $\begin{array}{c}\text { Resistance } \\
\text { Load }\end{array}$ & $15.000 \mathrm{~W}$ \\
\hline Temperatur display & 5 channel & \\
\hline Volt meter & AC/DC & \\
\hline Clamp meter & AC/DC & \\
\hline Toolset & & \\
\hline
\end{tabular}

\section{Metode Penelitian}

Penelitian ini merupakan penelitian eksperimental dimulai dengan melakukan studi pustaka terhadap penelitian sejenis yang pernah dilakukan melalui jurnal ilmiah nasional dan internasional, mempelajari paten yang telah ada, mempelajari handbook serta mencari data pasar dari pelaku usaha otomotif tentang penggunaan motor bakar berbahan bakar gas. Melakukan penelaahan formula perhitungan bahan bakar gas pada motor bakar. Metode berikutnya yaitu melakukan identifiasi desain konseptual dari bagian-bagian motor bakar yang perlu dilakukan modifikasi apabila menggunakan bahan bakar gas. Metode selanjutnya yaitu melakukan pengujian performa motor bakar dengan menggunakan bahan bakar bensin dan menggunakan bahan bakar gas. Data yang didapat dari proses pengujian kemudian dianalisa dan dibandingkan dengan data hasil studi literatur kemudian diambil kesimpulan dari hasil analisa tersebut. Berikut ini ditampilkan flow chart dari penelitian yang dilakukan: 


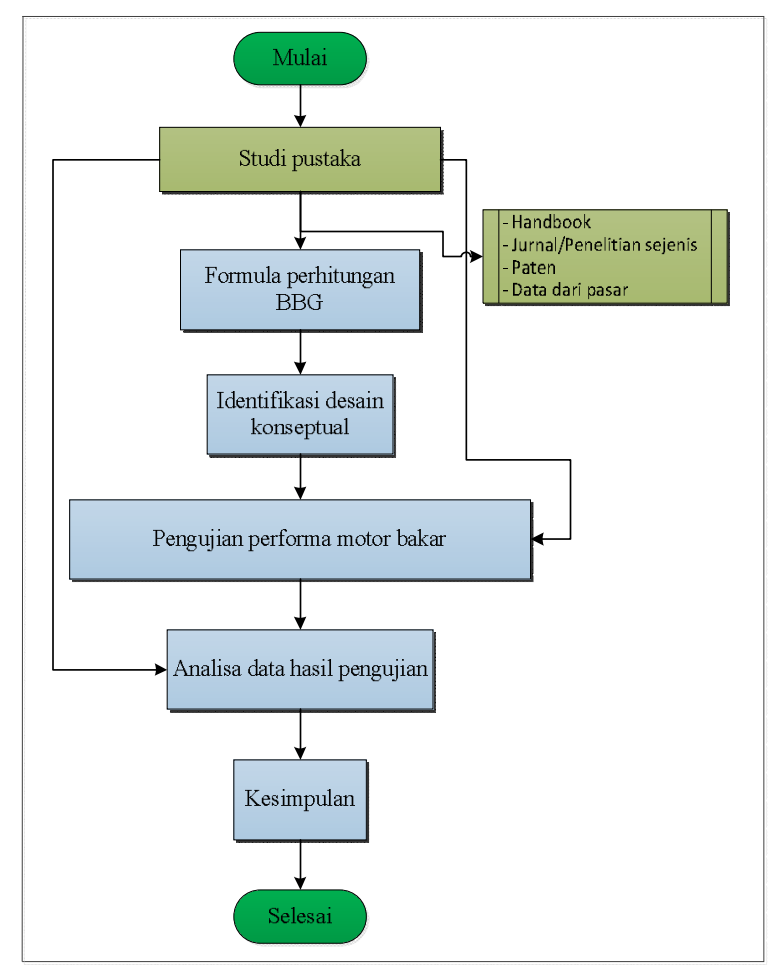

Gambar 2. Diagram alir penelitian yang dilakukan

\section{HASIL PENELITIAN}

Hasil pelaksanaan penelitian yang telah dilakukan terdiri dari pengujian motor bakar sebagai objek penelitian dengan menggunakan bahan bakar bensin dan bahan bakar gas. Dari kedua pengujian yang dilakukan didapat data primer hasil pengukuran terhadap beberapa komponen motor bakar yang diidentifikasi akan terpengaruh akibat dari perubahan penggunaan bahan bakar.

Pada pengujian ini, penelitian difokuskan pada karakterisasi motor bakar sebagai objek untuk reverse engineering. Pengujian performa motor bakar dilakukan pada daya keluaran dari motor bakar tersebut, dimaksudkan agar memperoleh data awal sebagai dasar/acuan untuk melakukan modifikasi atau reverse engineering. Pengujian dilakukan dengan mengoperasikan motor bakar yang dikopel dengan generator pembangkit tenaga listrik, dari generator dipasang beban (load) yang besar pembebanannya divariasikan dengan interval waktu. Pemberian beban maksimal dilakukan hingga motor bakar tidak mampu beroperasi lagi sehingga didapat data kemampuan motor bakar yang dilengkapi dengan data-data pengukuran sebagai penunjang performa dari motor bakar tersebut. Berikut ini ditampilkan gambar dari motor bakar sebagai objek penelitian.

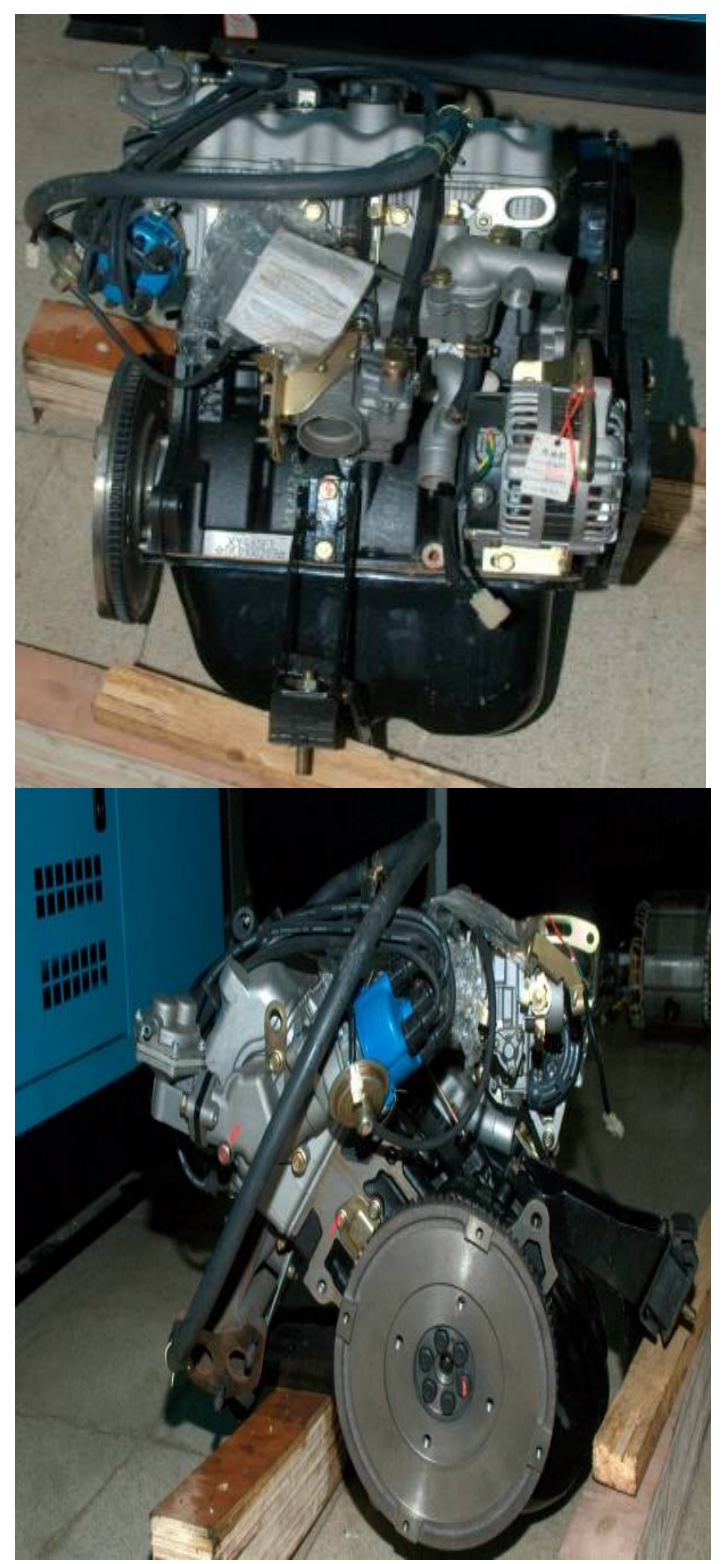

Gambar 3. Motor bakar yang digunakan sebagai objek penelitian

Motor bakar sebagai objek penelitian yang akan diuji disiapkan untuk pelaksanaan pengujian dengan melakukan pemasangan sensor-sensor agar memudahkan pada saat proses pengambilan data. sensor yang dipasang pada motor bakar yaitu diantaranya: sensor pengukur temperatur udara masuk/intake air (T1); sensor pengukur temperatur gas buang knalpot (T2); sensor pengukur temperatur air pendingin (T3); sensor pengukur temperatur oli pelumas (T4); sensor pengukur temperatur body stator pada generator (T5); sensor pengukur temperatur exhaust manifold (T6); sensor pengukur temperatur cylinder head 
(T7), pada generator yang dikopel dengan motor bakar dipasang alat ukur Ampere meter, Volt meter, Frekuensi meter, Tacho meter.

Metode pengujian motor bakar yang dilakukan yaitu: (1) menjalankan motor bakar dengan bahan bakar bensin kemudian dilakukan pembebanan pada daya keluaran generator yang dikopel dengan motor bakar. Pembebanan menggunakan beban resistan yang berupa heater dengan interval waktu penambahan beban setiap 10 menit. Setiap 10 menit dilakukan pengambilan data pengukuran kemudian dicatat. Pemberian beban dilakukan hingga didapat beban maksimal hingga motor bakar tidak dapat beroperasi lagi. (2) menjalankan motor bakar dengan bahan bakar gas alam elpiji kemudian dilakukan metode yang sama. Berikut ini ditampilkan gambar bagian-bagian motor bakar yang digunakan sebagai objek penelitian.

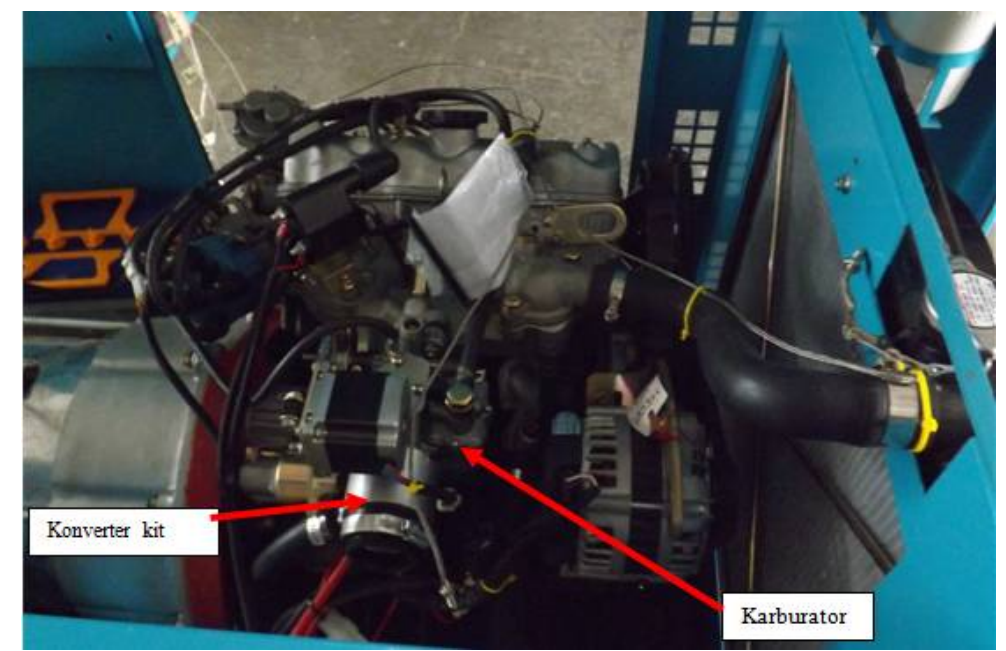

Gambar 4. Motor bakar yang dilengkapi dengan karburator dan konverter kit

Pada gambar diatas motor bakar sebagai objek penelitian dilihat dari pandangan atas, motor bakar tersebut dikopel dengan generator dan dilengkapi dengan dua sistem penyaluran bahan bakar yaitu dengan menggunakan karburator dan konverter kit.
Karburator berfungsi untuk menyalurkan bahan bakar bensin ke ruang bakar sedangkan konverter kit berfungsi menyalurkan bahan bakar gas ke ruang bakar melalui intake manifold.

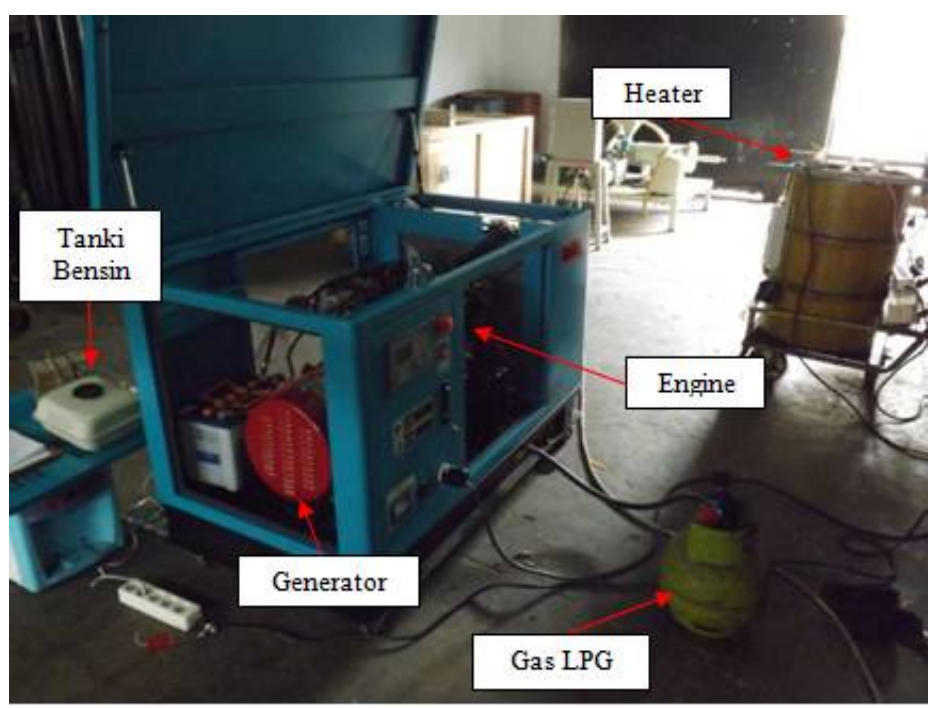

Gambar 5. Foto pengujian motor bakar 
Pada gambar diatas, pengujian motor bakar dilakukan dengan menggunakan bahan bakar bensin dan gas LPG. Generator dikopel dengan motor bakar untuk menghasilkan listrik. Beban resistif berupa heater/pemanas air dihubungkan ke generator dengan variasi beban dinaikan bertahap, hal tersebut dilakukan untuk mendapatkan data temperatur yang berbanding dengan kenaikan beban.

\section{PEMBAHASAN}

Dari hasil pengujian pertama dengan menggunakan bahan bakar bensin didapat data hasil pengukuran temperatur pada beberapa komponen motor bakar seperti terlihat pada gambar kurva dibawah ini.

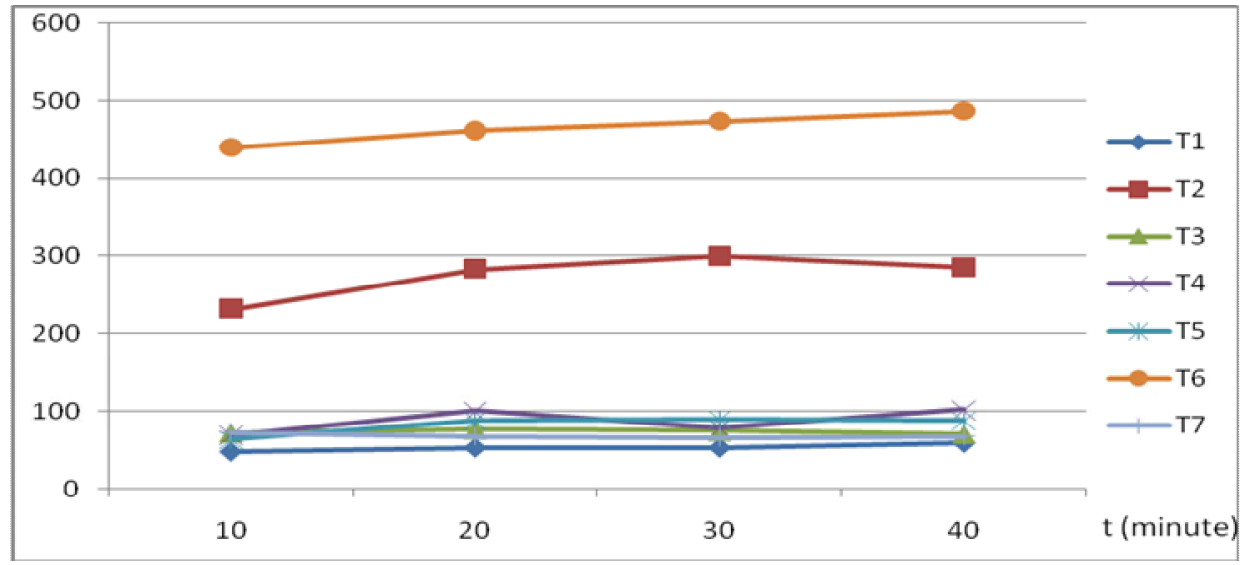

Gambar 6. Data Pengujian Motor Bakar Dengan Bahan Bakar Bensin

Pada gambar kurva diatas, motor bakar dijalankan dengan menggunakan bahan bakar bensin kemudian dilakukan pembebanan secara bertahap setiap 10 menit setelah itu dilakukan pengambilan data temperatur pada beberapa komponen motor bakar, T1 merupakan temperatur udara masuk/intake air; T2 merupakan temperatur gas buang pada ujung knalpot/muffler; T3 merupakan temperatur pada air radiator; T4 merupakan temperatur oli pelumas; T5 merupakan temperatur pada gulungan kabel stator generator set; T6 merupakan temperatur pada header knalpot/exhaust manifold; dan T7 merupakan temperatur pada cylinder head.

Pengujian kedua dilakukan dengan pada motor bakar yang sama namun dengan menggunakan bahan bakar yang berbeda yaitu bahan bakar gas LPG $12 \mathrm{Kg}$. Metoda pengujian yang dilakuakn sama dengan metode pengujian dengan bahan bakar bensin yaitu generator set yang dikopel dengan motor bakar diberi pembebanan secara bertahap dan setiap 10 menit dilakukan pengambilan data temperatur seperti pada gambar kurva dibawah ini.

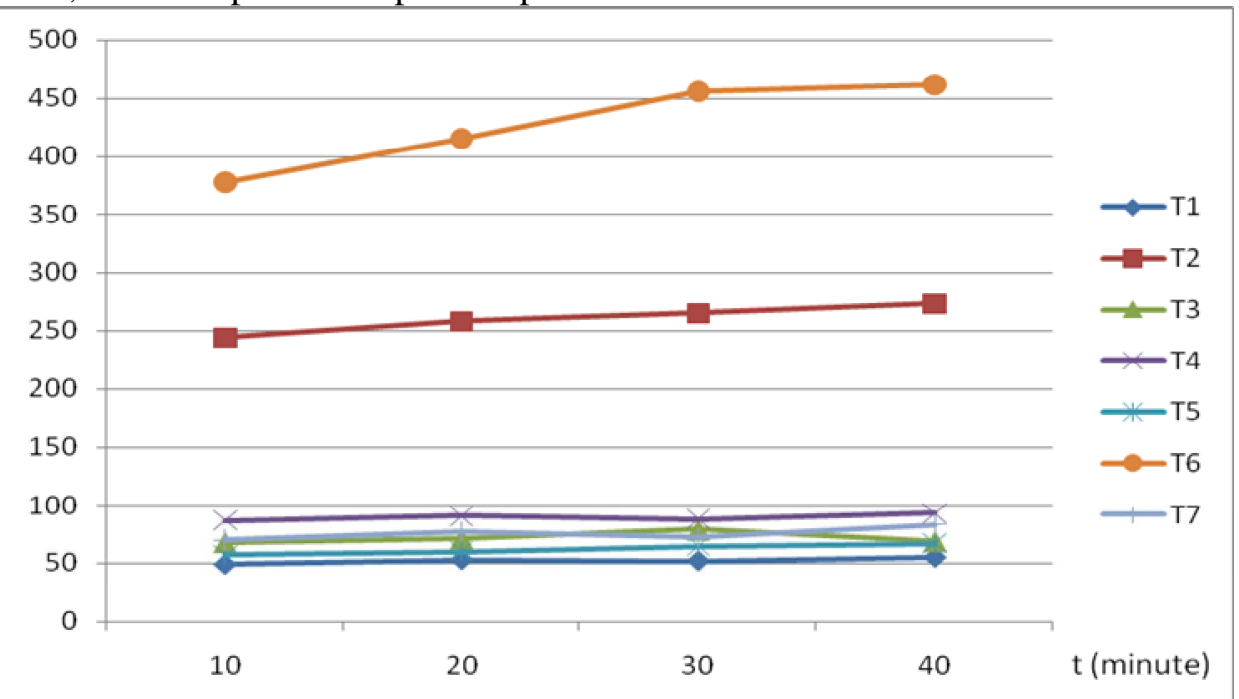

Gambar 7. Data pengujian motor bakar dengan bahan bakar elpiji 
Dari hasil pengujian pertama dan kedua dengan menggunakan bahan bakar yang berbeda terdapat beberapa perbedaan temperatur pada beberapa komponen motor bakar. Namun perbedaan temperatur yang ditampilkan pada gambar 4 dan gambar 5 tidak terlalu signifikan, hal ini dapat disimpulkan bahwa penggunaan bahan bakar bensin dan gas LPG tidak terlalu berpengaruh terhadap temperatur komponen-komponen yang berhubungan dengan proses pembakaran seperti: temperatur cylinder head, temperatur header knalpot/exhaust manifold, temperatur oli pelumas, dan temperatur air radiator. Hal ini mengindikasikan bahwa material yang digunakan untuk komponen-komponen motor bakar berbahan bakar bensin dapat juga digunakan untuk motor bakar berbahan bakar gas LPG, perubahan/modifikasi hanya diperlukan pada fuelling system.

\section{KESIMPULAN DAN SARAN}

\section{Kesimpulan}

Dari studi/penelitian mengenai eksplorasi motor bakar berbahan bakar ganda dalam rangka mendukung pengembangan motor bakar berbahan bakar gas alam dapat disimpulkan tidak ada perbedaan temperatur yang signifikan pada beberapa komponen motor bakar yang menggunakan bahan bakar bensin dan bahan bakar gas LPG. Material yang digunakan komponen motor bakar berbahan bakar bensin seperti komponen cylinder head dapat juga digunakan untuk bahan bakar gas namun sirkulasi oli pelumas dan water coolant harus berfungsi dengan baik.

Untuk menambah dan melengkapi penelitian motor bakar gas ini, pada percobaan yang telah dilakukan, gas alam yang digunakan adalah gas LPG untuk itu perlunya penelitian lanjutan untuk meneliti dampak penggunaan gas alam lain seperti compressed natural gas (CNG) atau liquid gas for vehicle (LGV) mengingat karakteristik setiap gas alam tersebut berbeda-beda.

\section{Ucapan Terima Kasih}

Penulis memanjatkan puji syukur ke khadirat Allah SWT. Terima kasih kepada Sdr. Luky krisnadi, ST. yang telah membantu dalam proses pengujian, pengumpulan data serta hasil pengukuran, rekan-rekan staf seksi perancangan teknik yang telah memberikan dukungan fasilitas. Rasa terima kasih juga penulis ucapkan kepada Bapak Agus Budiman, ST. yang telah memberikan pengarahan pada saat penelitian dan penulisan karya tulis ilmiah, serta rekan-rekan di MIDC yang turut membantu penelitian ini dan tidak dapat disebutkan satu persatu.

\section{DAFTAR PUSTAKA}

1. Van Basshuysen Richard, Schafer Fred, 2004, Internal Combustion Engine Handbook: Basics, Component, Systems, and Perspectives, SAE International, Warrendale, Pa. Hal. 270 - 275.

2. C.S. Wang and G.F Berry, 1985, Heat Transfer In Internal Combustion Engines, The American Society Of Mechanical Engineers, 345 E.47 St, NewYork. NY 10017.

3. Bonick Allan and Newbold Derek, 2011, A Practical Approach to Vehicle Engineering and Maintenance, ELSEVIER, United Kingdom.

4. Ehsani Mehrdad, Gao Yimin, Emadi Ali, 2010, Modern Electric, Hybrid Electric and Fuel Cell Vehicles, Fundamentals, Theory and Design, CRC Press, Boca Raton Florida USA.

5. Mi Chris, Masrurand M.Abul, Wenzhong Gao David, 2011, Hybrid Electric Vehicles Principles and Applications with Practical Perspectives, WILEY Publication, United Kingdom

6. A. Crola David, 2009, Automotive Engineering Powertrain, Chassis System and Vehicle Body, ELSEVIER, USA

7. Anonim, Lesson of Diesel Engine Components. 